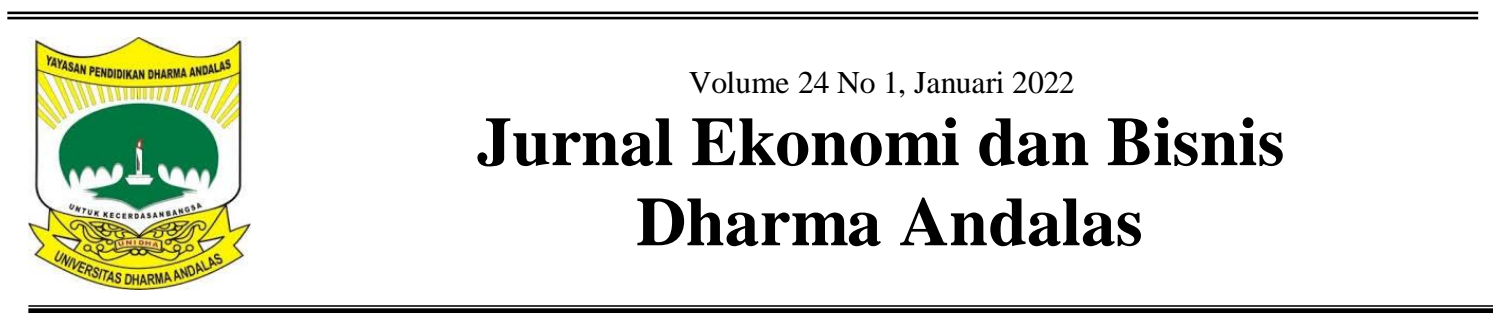

\title{
Faktor Faktor yang Mempengaruhi Opini Audit Going Concern Pada Perusahaan Manufaktur di Bursa Efek Indonesia
}

\author{
Syailendra Eka Saputra ${ }^{1}$, Alfattory Rheza Syahrul ${ }^{2}$, Gustia Harini ${ }^{3}$ \\ Fakultas Ekonomi dan Bisnis Universitas PGRI Sumatera Barat ${ }^{1,2,3}$ \\ email: syailend_ra@yahoo.com ${ }^{l}$
}

\begin{abstract}
This study aims to determine the effect of a number of factors that influence the provision of going concern audit opinions on manufacturing companies on the Indonesia Stock Exchange. In this study, the factors that are thought to influence the provision of going concern audit opinions consist of audit tenure, opinion shopping, audit delay and financial distress. The data analysis method used is binary logistic regression. Based on the results of hypothesis testing, it was found that audit tenure and opinion shopping had no significant effect on going concern audit opinions on manufacturing companies on the Indonesia Stock Exchange, while audit delay and financial distress had a significant effect on going concern audit opinions on manufacturing companies on the Indonesia Stock Exchange.
\end{abstract}

Keywords: audit tenure, opinion shoping, audit delay, financial distress \& audit opinion going concern

\begin{abstract}
ABSTRAK
Penelitian ini bertujuan mengetahui pengaruh sejumlah faktor yang mempengaruhi pemberian opini audit going concern pada perusahaan manufaktur di Bursa Efek Indonesia. Pada penelitian ini faktor yang diduga mepengaruhi pemberian opini audit going concern terdiri dari audit tenure, opinion shoping, audit delay dan financial distress. Metode analisis data yang digunakan adalah regresi binary logistic. Berdasarkan hasil pengujian hipotesis ditemukan audit tenure dan opinion shoping tidak berpengaruh signifikan terhadap opini audit going concern pada perusahaan manufaktur di Bursa Efek Indonesia, sedangkan audit delay dan financial distress berpengaruh signifikan terhadap opini audit going concern pada perusahaan manufaktur di Bursa Efek Indonesia.
\end{abstract}

Kata Kunci: audit tenure, opinion shoping, audit delay, financial distress \& opini audit going concern

\section{PENDAHULUAN}

Setiap perusahaan memiliki tujuan yang sama yaitu menjaga kelangsungan hidupnya dalam jangka panjang (Brigham dan Houston, 2017). Untuk menjaga kelangsungan hidup setiap perusahaan melakukan berbagai cara salah satunya mengelola kondisi keuangannya dengan sangat baik. Akan tetapi untuk mempertahankan kondisi keuangan yang ideal bagi perusahaan sangatlah sulit, mengingat pada saat ini persaingan yang terjadi antar perusahaan sangatlah ketat. Setiap perusahaan harus mencari solusi terbaik untuk menciptakan keunggulan bersaing agar kelangsungan hidup mereka dapat 
bertahan dalam jangka yang lebih panjang (Ross, et al., 2015).

Salah satu cara yang dilakukan perusahaan untuk menjaga kelangsungan hidupnya adalah menarik investor atau stakeholders agar berinvestasi di dalam perusahaan. Oleh sebab itu perusahaan harus memiliki laporan keuangan yng terpercaya. Laporan keuangan memiliki makna yang penting bagi stakeholders, karena laporan keuangan merupakan sarana untuk mendapatkan informasi sekaligus acuan dalam mengambil keputusan.

Dalam konsep teori keagenan menjelaskan hubungan antara principal (stakeholders) dan agen (menejer). Konflik kepentingan yang saling bertentangan antara manajer dan investor menjadi pemicu terjadi meningkatnya konflik keagenan, selain itu konflik keagenan juga membuat kualitas laporan keuangan menjadi menurun (Putra dan Purnamawati, 2021).

Menurut Fama dan Jensen, (2005) agen yang menyusun laporan keuangan perusahaan cenderung lebih mementingkan kepentingannya. Oleh karena itu peran auditor independen sangat dibutuhkan untuk mengurangi asimetris informasi antara kedua belah pihak.

Auditor independen dapat memberikan opininya atas laporan keuangan perusahaan yang terdiri dari neraca, laporan laba rugi, laporan arus kas hingga penjelasan atas laporan keuangan. Dengan demikian diharapkan pihak eksternal yang berkepentingan dapat membuat keputusan-keputusan untuk meningkatkan efisiensi pasar sesuai dengan infornasi yang telah diaudit oleh auditor independen.

Auditor mempunyai tanggung jawab penuh atas opini yang akan diberikan terhadap laporan keuangan suatu perusahaan, baik opini audit going concern atau pun opini non going concern. Perusahaan akan menerima opini audit non going concern jika laporan keuangan yang telah disajikan sesuai dengan standar akuntansi yang berlaku umum, sebaliknya opini audit going concern akan diberikan ketika terdapat keraguan terhadap keberlanjutan usaha sebuah perusahaan. Dalam hal ini auditor memiliki tanggung jawab penuh untuk menjelaskan masalah masalah yang menyebabkan perusahaan tersebut menerima opini going concern karena opini tersebut merupakan berita buruk bagi perusahaan (Fama dan Jensen, 2005).

Opini audit going concern yang dikeluarkan auditor kepada sebuah perusahaan menunjukan bahwa adanya keraguan pihak auditor terhadap perusahaan terutama yang berkaian dengan kelangsungan eksistensi kegiatan usahanya. Fenomena yang berkaitan dengan opini audit going concern terjadi pada PT Tiga Pilar diakhir tahun 2019 perusahaan tersebut mengalami kerugian berturut turut dalam tiga tahun yaitu dari tahun 2016 sampai dengan 2019, selain itu PT Tiga Pilar juga melakukan penggelembungan dana operasional sehingga merugikan stakeholders.

Ketika dilakukan kegiatan audit independen, manajemen PT Tiga Pilar terindikasi melakukan fraud (kecurangan) karena telah menggelembungkan dana dan memberikan informasi palsu kepada stakeholder. Temuan yang diperoleh team audit independen dan OJK tersebut mengakibat PT Tiga Pilar terancam dihapus dari perdagangan di Bursa Efek Indonesia, serta mendapatkan sanksi berupa suspend sementara untuk melakukan aktifias perdagangan di pasar sekunder, disamping itu manajemen perusahaan juga dikenakan denda lebih kurang 8 Milyar. Etikat baik yang dilakukan manajemen yang bersifat coporative dalam investigasi, mendorong 
dikeluarkannya izin kembali bagi perusahaan untuk melakukan aktifitas perdagangan di pasar sekunder setelah memperbaiki ketepatan dan kelengkapan informasi didalam laporan keuangan mereka.

Opini audit going concern akan mempengaruhi reputasi perusahaan sehingga sangat penting untuk dijadikan bahan kajian penelitian. Menurut Syahputra dan Yahya, (2017) mengungkapkan bahwa opini audit going concern dapat dipengaruhi oleh audit tenure, opinion shopping, dan audit delay. Hal yang berbeda diungkapkan oleh Saputra dan Kustina, (2018) yang mengungkapkan opini audit going concern dapat dipengaruhi oleh financial distress.

Audit tenure menunjukan jangka waktu yang dilalui oleh seorang auditor untuk bekerja sama dengan sebuah perusahaan (Belkaoui, 2015). Semakin panjang masa kontrak kerja antara auditor dengan perusahaan, akan mengakibatkan opini yang bias, karena ketika kontrak yang semakin panjang akan mendorong terbentuknya kerja sama auditor dengan manajer. Oleh sebab itu banyak perusahaan memilih menggunakan KAP yang bereputasi dan membatasi masa kontrak kerja auditor, agar opini audit yang dipublikasikan adalah opini yang didasarkan pada kondisi perusahaan yang sesungguhnya.

Hasil penelitian yang dilakukan oleh Ariska et al. (2019) yang menemukan bahwa audit tenure berpengaruh positif terhadap opini audit going concern. Temuan yang diperoleh oleh Syahputra dan Yahya (2017) juga menemukan bahwa semakin panjang tenure auditor maka akan semakin menurunkan opini audit going concern. Temuan yang berbeda diperoleh oleh Dewi dan Yuyetta (2014) menemukan bahwa audit tenure tidak berpengaruh signifikan terhadap opini audit going concern pada perusahaan go public di Bursa Efek Indonesai.

Opini audit going concern merupakan opini yang seharusnya bersifat independen akan tetapi dalam penentuannya diberikannya opini audit going concern dapat dipengaruhi oleh opinion shopping. Menurut Hunt et al. (2020) mengungkapkan bahwa opinion shopping merupakan perilaku manajer untuk melobi auditor agar mau memberikan opini audit sesuai dengan keinginan manajer, Ketika opinion shopping mampu mempengaruhi auditor yang akan memberikan opini, tentu opini yang terbentuk tindak menunjukan kondisi yang sesungguhnya.

Hasil penelitian yang dilakukan oleh Fahmi, (2016) menemukan opinion shopping berpengaruh positif terhadap opini audit going concern. Temuan yang sejalan juga diperoleh oleh Kwarto, (2017) yang menemukan opinion shopping berpengaruh negatif terhadap opini audit going concern Hasil yang berbeda diperoleh oleh Syahputra dan Yahya, (2017) yang menemukan bahwa opinion shopping tidak berpengaruh signifikan terhadap opini audit going concern pada perusahaan go publik di Bursa Efek Indonesia.

Pemberian opini audit going concern juga dapat dipengaruhi oleh audit delay. Menurut Alvin et al. (2012) audit delay adalah penundaan penyelesaian pembuatan laporan keuangan audit, terhitung dari tanggal tutup buku hingga 120 hari setelah tutup buku. Penundaan penyelsaian dan publikasi laporan keuangan menunjukan besar kemungkinan opini audit going concern akan diberikan auditor pada perusahaan.

Hasil penelitian Hasanuddin et al. (2019) menemukan bahwa audit delay berpengaruh negatif terhadap opini audit going concern. Hasil penelitian ini juga didukung oleh Syahputra dan Yahya 
(2017) yang menemukan audit delay berpengaruh negatif terhadap opini audit going concern.

Hasil penelitian Nainggolan, (2016) menemukan bahwa audit delay berpengaruh terhadap opini audit going concern pada sebuah perusahaan. Temuan tersebut mengisyaratkan ketika waktu penundaan laporan keuangan semakin pendek menunjukan tinggi kepercayaan diri pihak internal dan auditor pada pencapaian kinerja perusahaan, sekaligus menunjukan kemampuan perusahaan untuk bertahan hidup baik untuk jangka panjang atau pun jangka pendek semakin baik.

Opini audit going concern juga dapat diberikan oleh auditor independen kepada perusahaan juga dapat didorong karena terjadinya financial distress. Menurut Ross et al. (2015) mengungkapkan financial distress menunjukan terjadinya penurunan kinerja keuangan didalam sebuah perusahaan sehingga memicu perusahaan tersebut kesulitan untuk menenuhi kewajibannya kepada stakeholder seperti kreditur, investor atau pemegang saham. Semakin tinggi risiko sebuah perusahaan untuk mengalami financial maka akan semakin besar pula kemungkinan adanya opini audit going concern.

Hasil penelitian Saputra dan Kustina, (2018) menemukan bahwa financial distress berpengaruh positif terhadap opini audit going concern. Hasil penelitian yang sejalan juga diperoleh oleh Ardianto dan Trisnawati, (2018) yang mengungkapkan bahwa semakin tinggi risiko terjadinya financial distress maka akan semakin meningkatkan opini audit going concern pada sebuah perusahaan. Selanjutnya hasil penelitian yang berbeda diperoleh oleh Sinarto \& Wenny, (2018) menemukan bahwa financial distress tidak berpengaruh signifikan terhadap opini audit going concern.

\section{METODE PENELITIAN}

Penelitian yang dilaksanakan ini merupakan penelitian kuantitatif yaitu penelitian yang menggunakan pendekatan statistik untuk membuktikan kebenaran hipotesis (Sekaran, 2017). Pada penelitian ini metode analisis yang digunakan adalah analisis regresi logistic yang diolah dengan menggunakan SPSS versi 25.0

Menurut Sugiyono (2014) populasi merupakan seluruh atribut yang saling bekerja sama untuk mencapai satu tujuan tertentu. Dalam penelitian ini yang menjadi populasi adalah seluruh perusahaan sektor manufaktur yang terdaftar di Bursa Efek Indonesia dari tahun 2016 sampai 2020.

Untuk memilih perusahaan yang tepat maka digunakan metode purposive sampling. Menurut Sekaran (2017) purposive sampling adalah metode pengambilan sampel yang dilakukan dengan menentukan kriteria khusus pada populasi yang akan terpilih sebagai sampel. Kriteria yang digunakan meliputi:

1.Perusahaan manufaktur di BEI yang mempublikasikan laporan keuangan lengkap sepanjang tahun 2016 - 2020

2. Perusahaan manufaktur yang melakukan audit delay dari tahun 2016 sampai dengan 2020 yang lalu

3. Perusahaan yang menyediakan informasi lengkap tentang kebutuhan variabel yang digunakan

Pada penelitian ini variabel penelitian yang digunakan dapat dikelompokan menjadi dua kelompok utama yaitu:

\section{Opini Audit Going Concern}

$$
\text { Ross, et al. }
$$

mengungkapkan opini audit going concern sebagai persepsi atau penilaian yang diberikan oleh auditor untuk menjelaskan kemampuan sebuah perusahaan dalam mempertahankan kelangsungan hidupnya. Untuk 
mengukur opini audit going concern peneliti mengacu kepada dua penilaian yang diberikan, dimana untuk mengukur penilaian tersebut digunakan pengukuran dummy yang diadopsi dari Kwarto, (2017) yaitu:

- Perusahaan yang mendapatkan opini wajar tanpa pengecualian $=1$

- Perusahaan yang mendapatkan opini wajar dengan pengecualian $=0$

\section{Audit Tenure}

Gajevszky (2014) tenure merupakan jangka waktu atau masa bagi seseorang untuk menjabat dalam sebuah ikatan wewenang dan tanggung jawab. Dalam penelitian ini audit tenure yang dimaksud adalah lamanya sebuah Kantor Akuntan Publik (KAP) menjalin kerja sama dengan perusahaan yang diukur dengan tahun.

\section{Opinion Shopping}

Menurut Bernard (2017) opinion shopping merupakan penilaian atau pendapat dari pihak eksekutif khusus manajemen perusahaan untuk memutuskan melakukan pergantian auditor. Pada penelitian ini pengukuran opinion shopping diadopsi dari Hunt, et al. (2020) digunakan dummy dengan kriteria sebagai berikut:

- Perusahaan yang melakukan pergantian auditor setelah dikeluarkannya opini audit $=1$

- Perusahaan yang tidak melakukan pergantian auditor setelah dikeluarkannya opini audit $=0$

\section{Audit Delay}

Ardianto dan Trisnawati (2018) mendefinisikan audit delay sebagai waktu yang dibutuhkan perusahaan untuk mempublikasikan laporan keuangannya. Dihitung dari hari setelah tutup buku hingga laporan keuangan dipublikasikan. Dalam mengukur audit delay diadopsi dari Syahputra dan Yahya (2017) yang dengan menghitung jumlah hari dari periode tutup buku hingga perusahaan mempublikasikan laporan keuangannya, atau dapat dicari dengan Logaritma Natural (LN) selisih jumlah hari pada saat laporan keuangan audit ditanda tangani dengan periode tutup buku

\section{Financial Distress}

Ross et al. (2015) financial distress merupakan sebuah opini yang menunjukan sebuah situasi dimana perusahaan diprediksi mengalami masalah keuangan. Menurut Jamulddin, (2018) dalam mengukur financial distress maka digunakan kemampuan perusahaan dalam mengelola utang yang terlihat debt to equity ratio dimana dapat dirumuskan sebagai berikut:

$$
D E R=\frac{\text { Total Hutang }}{\text { Total Ekuitas }}
$$

Untuk membuktikan kebenaran hipotesis yang diajukan didalam penelitian ini maka digunakan analisis kuantitatif yaitu dengan menggunakan analisis regresi binary logistic.

Digunakan alat analisis tersebut karena variabel dependen yang digunakan menggunakan dummy 0 dan 1. Prosedur pengujian dilakukan dengan melaksanakan uji persyaratan yaitu -2 loglikelihood, pengujian Hosmer and Lemeshow, Analisis Negelkerke Rsquare, Pembentukan model Regresi Binary Logistic dan pengujian hipotesis dengan menggunakan Wald test

\section{HASIL DAN PEMBAHASAN Statistik Deskriptif}

Setelah seluruh data dan informasi berhasil dikumpulkan maka pengolahan data dapat dilaksanakan. Proses pengolahan data dilakukan dengan menggunakan bantuan program SPSS. Berdasarkan tahapan pengolahan data yang telah dilakukan diperoleh statistik deskriptif seperti terlihat pada Tabel 1 di bawah ini: 
Tabel 1

Statistik Deskriptif Variabel Penelitian

\begin{tabular}{lccccc}
\hline \multicolumn{1}{c}{ Variabel } & N & Min & Maks & Mean & $\begin{array}{c}\text { Std } \\
\text { Deviasi }\end{array}$ \\
\hline $\begin{array}{l}\text { Going } \\
\text { Concern }\end{array}$ & 315 & 0 & 1 & 0.87 & 0.33 \\
Audit tenure & 315 & 1 & 5 & 2.69 & 1.29 \\
$\begin{array}{l}\text { Opinion } \\
\text { Shopping }\end{array}$ & 315 & 0 & 1 & 0.03 & 0.17 \\
Audit Delay & 315 & 1.69 & 2.08 & 1.79 & 0.07 \\
$\begin{array}{l}\text { Financial } \\
\text { Distress }\end{array}$ & 315 & -4.42 & 14.69 & 1.18 & 1.87 \\
\hline
\end{tabular}

Pada tabel 1 terlihat bahwa jumlah data yang diolah berjumlah 105 obsevasi, dari statistik deskriptif terlihat variabel opini audit going concern diukur dengan menggunakan dummy, dimana skor terendah yang dihasilkan adalah 0 sedangkan skor tertinggi yang diperoleh adalah 1. Rata-rata skor nilai yang dihasilkan dalam proses pengukuran variabel going concern adalah sebesar 0,87 dengan standar deviasi mencapai 0,33 . Sejalan dengan rata rata yang diperoleh dapat disimpulkan bahwa sebagian besar perusahaan sektor manufaktur mendapatkan opini non going concern.

Berdasarkan hasil statistik deskriptif juga diketahui variabel audit tenure memiliki jumlah tahun perikatan terendah adalah sebesar 1 tahun sedangkan nilai perikatan dengan tahun tertinggi adalah sebesar 5 tahun. Rata rata masa perikatan auditor dalam perusahaan sektor manufaktur di Bursa Efek Indonesia adalah sebesar 2,69 tahun dengan standar deviasi mencapai 1,29 tahun. Berdasarkan rata-rata yang diperoleh dapat disimpulkan bahwa masa perikatan auditor dengan perusahaan klien berkisar antara dua sampai tiga tahun.

Selain itu pada proses tabulasi ditemukan variabel opinion shopping diukur dengan kategori, dimana kategori paling rendah yang ditetapkan adalah 0 sedangkan kategori tertinggi adalah 1. Secara keseluruhan nilai rata rata opinion shoping yang dimiliki perusahaan sektor manufaktur adalah sebesar 0,03 dengan standar deviasi data mencapai 0,16. Mengacu pada rata-rata opinion shopping yang diperoleh dapat disimpulkan sebagian besar perusahaan tidak melakukan pergantian auditor setelah auditor yang memiliki perikatan dengan perusahaan mengeluarkan opini audit.

Pada proses tabulasi data juga diketahui nilai audit delay paling rendah adalah sebesar 49 hari sedangkan jumlah hari penundaan terpanjang dari salah satu perusahaan sektor manufaktur dalam menyelesaikan dan mempublikasikan laporan keuangan adalah sebesar 120 hari. Rata-rata jumlah hari penundaan penyelesaian dan publikasi yang dimiliki perusahaan sektor manufaktur di Bursa Efek Indonesia adalah sebesar 61.85 hari dengan standar deviasi mencapai 11.37 hari.

Dalam proses tabulasi juga diketahui nilai financial distress paling rendah yang dimiliki salah satu perusahaan sektor manufaktur di Bursa Efek Indonesia adalah sebesar -4.42 sedangkan nilai financial distress tertinggi mencapai 14,69. Rata rata prediksi kondisi financial distress yang dimiliki pada umumnya perusahaan sektor manufaktur di Bursa Efek Indonesia adalah sebesar 1,18 dengan standar deviasi mencapai 1,87.

\section{Analisis Regresi Binary Logistic}

Uji Spesifikasi -2 Loglike Lihood

Sebelum dilakukan tahapan pengujian hipotesis terlebih dahulu dilakukan pengujian persyaratan analisis regresi binary logistic. Prosedur yang dilakukan adalah sebagai berikut: 
Tabel 2

\begin{tabular}{ccc}
\multicolumn{3}{c}{ Model Pengujian - 2 Likelihood Test } \\
\hline Model & $\mathbf{- 2}$ Log likelihood & Selisi \\
\hline Blog 0 & 239,786 & 12.853 \\
Blog 1 & 226.933 & \\
\hline
\end{tabular}

Sesuai dengan hasil pengolahan data yang telah dilakukan terlihat bahwa nilai koefisien -2 log likelihood pada blog 0 adalah sebesar 239,786 terkoreksi atau mengalami penurunan pada model blog 1 sebesar 226,933 atau menurun sebesar 12,853 dengan demikian pemilihan variabel yang akan membentuk sebuah persamaan regresi binary logistic merupakan variabel yang tepat, sehingga dapat terus digunakan kedalam tahapan pengolahan data lebih lanjut.

\section{Pengujian Hosmer and Lemeshow}

Pengujian Hosmer and

Lemeshow berguna untuk memastikan bahwa model regresi binary logistic yang akan dianalisis Berdasarkan hasil pegolahan data yang telah dilakukan diperoleh ringkasan hasil pada Tabel 3 di bawah ini:

Tabel 3

\begin{tabular}{cccc}
\multicolumn{4}{c}{ Pengujian Hosemer } \\
\hline Step & chi Lquare & Lemeshow & sig \\
\hline 1 & 6,681 & 8 & 0,571 \\
\hline
\end{tabular}

Berdasarkan hasil pengujian diperoleh nilai sig yang dihasilkan dalam pengujian adalah sebesar 0,571. Hasil yang diperoleh tersebut menunjukan bahwa nilai sig sebesar 0,571 jauh diatas 0,05 . Dengan demikian variabel yang akan digunakan untuk membentuk model regresi binary logistic dalam model penelitian saat ini relatif tepat. Oleh sebab itu tahapan pengolahan data lebih lanjut dapat segera dilakukan.

\section{Pengujian Nelgerke R-square}

Pengujian Nelgerker $R$-square bertujuan untuk mengetahui kemampuan dari seluruh variabel independen yang telah dibentuk kedalam model persamaan regresi binary logistic dalam mempengaruhi variabel dependen yang diukur dengan persentase. Berdasarkan hasil pengolahan data yang telah dilakukan diperoleh ringkasan hasil terlihat pada Tabel 4 di bawah ini:

Tabel 4

Pengujian Negelkerke R-Square

\begin{tabular}{cc}
\hline Step & Nagelkerke $R$ Square \\
\hline 1 & 0,075 \\
\hline
\end{tabular}

Sesuai dengan hasil pengujian terlihat nilai Negelkerke $R$-square yang dihasilkan adalah sebesar 0.075. Hasil yang diperoleh tersebut menunjukan audit tenure, opinion shopping, audit delay, dan financial distress hanya mampu memberikan kontribusi dalam mempengaruhi terjadinya opini audit going concern pada perusahaan sektor manufaktur di Bursa Efek Indonesia adalah sebesar $7.50 \%$ sedangkan sisanya sebesar $92.50 \%$ lagi dipengaruhi oleh variabel lain yang tidak digunakan dalam model penelitian saat ini.

\section{Hasil Pengujian Hipotesis}

Dalam rangka mengetahui besar dan arah pengaruh yang terbentuk antara variabel independen terhadap variabel dependen maka dilakukan pembentkan model regresi binary logistic seperti terlihat pada Tabel 5 di bawah ini:

Tabel 5

Hasil Pengujian Hipotesis

\begin{tabular}{lcccc}
\hline \multicolumn{1}{c}{ Keterangan } & $\begin{array}{c}\text { Koefisien } \\
\text { Regresi }\end{array}$ & Sig & $\begin{array}{c}\text { Cut } \\
\text { off }\end{array}$ & Kesimpulan \\
\hline Constanta & 7.775 & & & \\
Audit tenure & -0.001 & 0,992 & 0,05 & $\mathrm{H}_{1}$ Ditolak \\
$\begin{array}{l}\text { Opinion } \\
\text { Shopping }\end{array}$ & 19,229 & 0,999 & 0,05 & $\mathrm{H}_{2}$ Ditolak \\
$\begin{array}{l}\text { Audit Delay } \\
\begin{array}{l}\text { Financial } \\
\text { Distress }\end{array}\end{array}$ & $-3,456$ & 0,018 & 0,05 & $\mathrm{H}_{3}$ Diterima \\
\hline
\end{tabular}

Sesuai dengan model persamaan regresi binary logistic diperoleh nilai konstanta sebesar 7,775. Nilai koefisien tersebut menunjukan jika diasumsikan tidak terjadi perubahan seluruh variabel 
independen yang terdiri dari audit tenure, opinion shopping, audit delay, dan financial distress maka besarnya kemungkinan terjadinya opini audit going concern adalah sebesar 7,775. Nilai koefisien yang diperoleh tersebut mengisyaratkan bahwa kecenderungan terjadi risiko opini audit going concern pada perusahaan sektor manufaktur di Bursa Efek Indonesia masih relatif tinggi.

Berdasarkan hasil pengujian hipotesis pertam terlihat variabel audit tenure memiliki koefisien regresi bertanda negatif sebesar 0.001 nilai koefisien tersebut diperkuat dengan nilai sig sebesar 0,992.. Hasil yang diperoleh tersebut menunjukan nilai sig sebesar 0,992 jauh diatas 0,05 maka dapat disimpulkan audit tenure tidak berpengaruh signifikan terhadap opini audit going concern pada perusahaan sektor manufaktur di Bursa Efek Indonesia.

Pada tahapan pengujian hipotesis kedua dengan menggunakan variabel opinion shopping diperoleh hilai koefisien regresi bertanda negatif sebesar -3.456. Nilai koefisien tesebut secara statistik memiliki nilai sig sebesar 0,999. Dengan demikian nilai sig 0,999 jauh di atas tingkat kesalahan 0,05. Maka dapat disimpulkan opinion shopping tidak berpengaruh signifikan terhadap opini audit going concern pada perusahaan manufaktur di Bursa Efek Indonesia.

Sesuai dengan hasil pengujian hipotesis ketiga terlihat bahwa variabel audit delay memiliki koefisien regresi bertanda negatif sebesar -3,456 yang diperkuat dengan nilai sig sebesar 0,018.. Dengan demikian nilai sig sebesar 0,018 jauh dibawah 0,05. Maka dapat disimpulkan audit delay berpengaruh negatif dan signifikan terhadap opini audit going concern pada perusahaan sektor manufaktur di Bursa Efek Indonesia.

Berdasarkan hasil pengujian hipotesis keempat dengan menggunakan variabel financial distress, diperoleh nilai koefisien regresi bertanda positif sebesar 0,372 yang dibuktikan secara statistik dengan nilai sig sebesar 0.014. Dengan demikian nilai sig sebesar 0,014 jauh dibawah 0,05. Maka dapat disimpulkan financial distress berpengaruh signifikan terhadap opini audit going concern pada perusahaan sektor manufaktur di Bursa Efek Indonesia.

\section{Pengaruh Audit tenure Terhadap Opini Audit Going Concern}

Hasil yang diperoleh menunjukan bahwa audit tenure bukanlah variabel yang mempengaruhi pemberian opini audit going concern pada perusahaan manufaktur di Bursa Efek Indonesia. Keadaan tersebut disebabkan di dalam bekerja auditor cenderung professional dan adil dalam bekerja, dimana opini yang terbentuk benar benar merupakan hasil pengamatan dan audit yang dilakukan auditor dan bukan opini yang terbentuk untuk memenuhi kepentingan seseorang. Oleh sebab itu masa perikatan atau tenure yang dimiliki auditor bukanlah variabel yang mempengaruhi terbentuknya opini audit going concern pada perusahaan manufaktur di Bursa Efek Indonesia.

Hasil yang diperoleh sejalan dengan teori yang dijelaskan oleh Mulyadi (2016) yang mengungkapkan pemberian opini audit going concern diberikan auditor atas banyak pertimbangan, dimana pertimbangan tersebut tidak hanya dipengaruhi oleh audit tenure. Temuan yang diperoleh juga sejalan dengan hasil penelitian Ricardo (2019) yang menemukan bahwa audit tenure tidak berpengaruh signifikan terhadap opini audit going concern, hasil yang sejalan juga 
diperoleh oleh Diana (2021) yang menyatakan bahwa audit tenure bukanlah variabel yang mempengaruhi terbentuknya opini audit going concern, melainkan opini tersebut muncul karena hasil investigasi yang intensif dari seluruh auditor.

\section{Pengaruh Opinion Shopping Terhadap Opini Audit Going Concern}

Temuan yang diperoleh pada tahapan pengujian hipotesis kedua menunjukan opinion shopping bukanlah satu satunya variabel yang mempengaruhi opini audit going concern pada perusahaan manufaktur. Keadaan tersebut disebabkan pendekatan yang dilakukan oleh manajer kepada auditor, tidak mempengaruhi keputusan auditor untuk memberikan opini yang sesuai dengan keadaan perusahaan yang sesungguhnya, selain opini tersebut merupakan opini yang jujur dan terpercaya dan bukan dinyatakan atas dasar keterpangsaan walaupun manajer berusahaan melakukan pendekatan personal kepada auditor dalam bekerja.

Hasil yang diperoleh konsisten dengan teori yang dijelaskan oleh Mulyadi (2016) yang mengungkapkan bahwa seorang auditor di dalam menjalankan tugasnya harus independen dan memiliki etika moral yang kuat, sehingga tidak mudah terbujuk kepentingan individu atau sekelompok orang. Temuan yang diperoleh pada tahapan pengujian hipotesis kedua juga didukung oleh hasil penelitian Juanita (2019) yang menemukan opinion shopping tidak berpengaruh signifikan terhadap opini audit going concern. Temuan yang diperoleh juga konsisten dengan hasil penelitian Rizaldi dan Dewi (2020) yang mengungkapkan bahwa opinion shopoing tidak mempengaruhi opini audit going concern yang diberikan auditor pada sebuah perusahaan, opini tersebut terbentuk kerena hasil audit yang berkualitas dan terpercaya.

\section{Pengaruh Audit Delay Terhadap Opini Audit Going Concern}

Hasil yang diperoleh tersebut menunjukan bahwa semakin panjang penundaan penyelesaian laporan keuangan audit oleh auditor semakin menurunkan kemungkinan bagi sebuah perusahaan untuk mendapatkan opini audit going concern. Keadaan tersebut disebabkan karena penundaan penyelesaian laporan keuangan audit akan memberikan kesempatan pada perusahaan yang diaudit untuk menutupi kekurangan dan kelemahan yang terdapat di dalam laporan keuangan. Penundaan waktu yang terjadi dapat mendorong munculnya penilaian yang bias sehingga cenderung menguntungkan bagi manajer atau perusahaan, dimana opini audit yang diberikan lebih cenderung opini non going concern.

Hasil yang diperoleh pada tahapan pengujian hipotesis ketiga sejalan dengan penelitian Fahmi (2016) yang menemukan bahwa audit delay berpengaruh negatif terhadap opini audit going concern. Temuan yang sejalan diperoleh oleh Syahputra dan Yahya (2017) yang menemukan audit delay berpengaruh negatif terhadap opini audit going concern.

Hasil penelitian Kwarto (2017) menemukan bahwa audit delay berpengaruh terhadap opini audit going concern pada sebuah perusahaan. Temuan tersebut mengisyaratkan ketika waktu penundaan laporan keuangan semakin pendek menunjukan tinggi kepercayaan diri pihak internal dan auditor pada pencapaian kinerja perusahaan, sekaligus menunjukan kemampuan perusahaan untuk betahan hidup baik untuk jangka panjang atau pun jangka pendek semakin baik.

Pengaruh Financial Distress Terhadap Opini Audit Going Concern

Pada tahapan pengujian hipotesis keenam terlihat bahwa financial distress 
berpengaruh positif terhadap opini audit going concern. Temuan tersebut menunjukan semakin tinggi risiko sebuah perusahaan untuk mendapatkan opini audit going concern maka akan semakin meningkatkan kemungkinan bagi perusahaan untuk mendapatkan opini audit going concern. Dengan demikian hipotesis keenam diterima. Keadaan tersebut terjadi karena ketika sebuah perusahaan dinyatakan berada pada situasi financial distress mengisyaratkan perusahaan tersebut sedang mengalami masaah keuangan yang ditandai dengan terjadinya penurunan laba usaha, meningkatkanya risiko kegagalan dalam membayar hutang, rendahnya perputaran aset hingga menurunnya kemampuan perusahaan dalam membayar dividen. Kondisi financial distress akan sejalan dengan pemberian opini audit going concern.

Temuan yang konsisten diperoleh oleh Saputra dan Kustina (2018) menemukan bahwa financial distress berpengaruh positif terhadap opini audit going concern. Temuan tersebut menunjukan ketika risiko terjadinya financial distress maka besar kemungkinan bagi perusahaan untuk mendapatkan opini audit going concern. Temuan yang tidak mendukung diperoleh oleh Sinarto dan Wenny (2018) yang menemukan financial distress tidak selamanya mempengaruhi opini audit going concern didalam sebuah perusahaan.

\section{SIMPULAN}

Sesuai dengan uriaan analisis dan pembahasan hasil pengujian hipotesis yang telah dilakukan maka diajukan beberapa kesimpulan penting yaitu Audit tenure tidak berpengaruh signifikan terhadap opini audit going concern pada perusahaan sektor manufaktur di Bursa Efek Indonesia. Hasil pengujian hipotesis kedua ditemukan opinion shopping tidak berpengaruh signifikan terhadap opini audit going concern pada perusahaan sektor manufaktur di Bursa Efek Indonesia. Pada tahapan pengujian hipotesis ketiga ditemukan audit delay berpengaruh negatif dan signifikan terhadap opini audit going concern pada perusahaan sektor manufaktur di Bursa Efek Indonesia selain itu pada tahapan pengujian hipotesis keempat ditemukan financial distress berpengaruh positif dan signifikan terhadap opini audit going concern pada perusahaan sektor manufaktur di Bursa Efek Indonesia.

$$
\text { Sesuai dengan uraian }
$$

kesimpulan, maka diajukan beberapa saran yang dapat memberikan saran yang dapat memberikan saran yang bermanfaat bag: perusahaan disarankan untuk mempertegas masa perikatan antara auditor dengan perusahaan, sehingga kecil kemungkinan adanya auditor yang memiliki tenure yang panjang dan memiliki kedekatan dengan manajer, kondisi tersebut tentu dapat mendorong audit yang lebih berkualtias serta menghindari kemungkinan bagi perusahaan untuk mendapatkan opini audit going concern.

Selain itu bagi perusahaan juga disarankan untuk menghindari terjadinya opinion shopping, dan memberikan kebebasan bagi auditor untuk melakukan kegiatan audit, saran tersebut penting untuk meningkatkan kualitas opini audit yang dihasilkan, dimana opini audit yang dikeluarkan dapat menjadi rekomendasi bagi perusahaan dalam menyusun kebijakan penting bagi kemajuan perusahaan dimasa mendatang. Disamping itu bagi peneliti dimasa mendatang disarankan untuk mencoba mencari sektor perusahaan lain, serta mencoba mencari variabel lain yang juga mempengaruhi opini audit going concern seperti cash turnover, risiko bisnis, opini audit going concern dan 
berbagai variabel lainnya. Saran tersebut penting untuk meningkatkan kualtitas hasil penelitian yang diperoleh dimasa mendatang.

\section{DAFTAR PUSTAKA}

Alvin Arens, Randal J, Elders, \& Mark, S, B. (2012). Auditing and Assurance Services an Integrated Approach. 14 Edition, Vol. 66). Upper Saddle River: Prentice-Hall.

Ardianto, T. D., \& Trisnawati, R. (2018). Pengaruh Opini Audit, Ukuran KAP, Pergantian Manajemen, Financial Distress, dan Profitabilitas Terhadap Voluntary Auditor Switching (Studi Empiris pada ..., 02(2), 19-52. Retrieved from

http://eprints.ums.ac.id/id/eprint/69 185

Ariska, E. Y., Maslichah, \& Afifudin. (2019). Pengaruh audit tenure, opinion shoppping, leverage dan pertumbuhan perusahaan terhadap penerimaaan opini audit going concern pada perusahaan manufaktur yang terdaftar di Bursa Efek Indonesia 2015-2017. EJurnal Riset Akuntansi, 8(6), 157170.

Belkaoui Ahmed Riahi. (2015). Accounting Theory (7th ed.). Irwin: McGraw-Hill.

Bernard, P. H. (2017). Business Analysis \& Evaluation Using Financial Statement (Third Edit). New Jersey: McGraw-Hill.

Brigham, E. F., \& Houston, J. F. (2017). Fundamentals of Financial Management (10 Edition). Pearson: Ptentice-Hall.

https://doi.org/10.1017/CBO978110 7415324.004

Dewi, S. G. P., \& Yuyetta, E. N. A. (2014). Pengaruh Kualitas Audit Dan Tenure Audit Terhadap Audit
Repot Lag (Arl) Dengan Spesialisasi Auditor Industri Sebagai Variabel Moderasi (Studi Empiris pada .... Diponegoro Journal Of Accounting, 3, 1-11. Retrieved from http://eprints.undip.ac.id/42915/

Fahmi, M. N. (2016). Pengaruh Audit Tenure, Opini Audit Tahun Sebelumnya, Dan Disclosure Terhadap Opini Audit Going Concern. Akuntabilitas, 8(3), 162170.

https://doi.org/10.15408/akt.v8i3.27 70

Fama, E. F., \& Jensen, M. C. (2005). Agency Problems and Residual Claims. SSRN Electronic Journal, $X X V I$ (June), 327-349. https://doi.org/10.2139/ssrn.94032

Gajevszky, A. (2014). Auditor Tenure And Financial Reporting Disclosure: Evidence From The Bucharest Stock Exchange. International Journal of Innovation and Applied Studies, 7(2), 421-433.

Hasanuddin, A. B., Wawo, A., \& Anwar, P. H. (2019). Pengaruh Company Growth Dan Audit Tenure Terhadap Opini Audit Going Concern Dengan Aduit Delay Sebagai Pemoderasi Pada Perusahaan Manufaktur Yang Terdaftar Di Bei 2014 - 2018. Jurnal Ilmiah Akuntansi Peradaban, 5(2), 176-196.

Hunt, J. O. S., Rosser, D. M., \& Rowe, S. P. (2020). Using machine learning to predict auditor switches: How the likelihood of switching affects audit quality among nonswitching clients. Journal of Accounting and Public Policy, (xxxx), 106785. https://doi.org/10.1016/j.jaccpubpol .2020 .106785

Jamulddin, M. (2018). The Effect Of Financial Distress And Disclosure 
On Going Concern Opinion Of The Banking Company Listing In Indonesian Stock Exchange. International Journal of Scientific Research and Management, 6(01). https://doi.org/10.18535/ijsrm/v6i1. em10

Kwarto, F. (2017). Pengaruh Opinion Shopping Dan Pengalaman Auditorterhadap Penerimaan Opini Audit Going Concern Dalam Sisi Pandang Perusahaan Auditan. Jurnal Akuntansi, 19(3), 311. https://doi.org/10.24912/ja.v19i3.82

Nainggolan, P. (2016). Analisis Pengaruh Audit Tenure, Ukuran Perusahaan, Opini Audit Tahun Sebelumnya, Kualitas Audit Terhadap Penerimaan Opini Audit Going Concern Pada Perusahaan Manufaktur. Jurnal Lentera Akuntansi, 2(2), 80-100.

Putra, W. M., \& Purnamawati, R. (2021). The Effect of Audit Tenure, Audit Delay, Company Growth, Profitability, Leverage, and Financial Difficulties on Acceptance of Going Concern Audit Opinions. Proceedings of the 4th International Conference on Sustainable Innovation 2020Accounting and Management (ICoSIAMS 2020), 176(ICoSIAMS 2020), 199-208. https://doi.org/10.2991/aer.k.21012 1.027

Ross, S. a, Westerfield, \& Jaffe. (2015). Corporate Finance, 9th Ed. Irwin: McGraw-Hill.

Saputra, E., \& Kustina, K. T. (2018). Analisis Pengaruh Financial Distress, Debt Default, Kualitas Auditor, Auditor Client Tenure, Opinion Shopping Dan Disclosure Terhadap Penerimaan Opini Audit Going Concern Pada Perusahaan Manufaktur Yang Terdaftar Di Bursa Efek Indonesia. Universitas
Pendidikan Nasional, Bali, 10(1), 52.

Sekaran, U. (2017). Research Methods for Business A Skill Building Approach (14th ed.). New York: John Wiey \& Sons Inc.

Sinarto, V., \& Wenny, C. D. (2018). Pengaruh Pertumbuhan Perusahaan, Pergantian Manajemen, Opini Audit, Financial Distress dan Ukuran Perusahaan Terhadap Auditor Switching ( Studi Empiris Pada Perusahaan Manufaktur Yang Terdaftar Di BEI. Jurnal Akuntansi STIE Multi Data Palembang, 12(3), $1-16$.

Sugiyono. (2014). Metode Penelitian Pendidikan Pendekatan Kuantitatif, Kualitatif dan $R \& D$. Bandung: Alfabeta.

Syahputra, F., \& Yahya, M. R. (2017). Pengaruh Audit Tenure, Audit Delay, Opini Audit Tahun Sebelumnya dan Opinion Shopping Terhadap Penerimaan Opini Audit Going Concern pada Perusahaan Manufaktur yang Terdaftar di Bursa Efek Indonesia Tahun 2013-2015. Jurnal Ilmiah Mahasiswa Ekonomi Akuntansi (JIMEKA), 2(3), 39-47. 